\title{
Okolica: wymiary postronności na wsi ${ }^{1}$
}

Karolina Koprowska

TEKSTY DRUGIE 2018, NR 3, S. 347-360

DOI: $10.18318 /$ td.2018.3.24

W obecnych badaniach nad wojną, Zagładą i relacjami polsko-żydowskimi zaznacza się kierunek ku ponownemu przemyśleniu tych doświadczeń, zorientowany na ich problematyzowanie, niuansowanie i ukontekstowienie; wypracowywanie takich narzędzi metodologicznych i pojęć, które pozwoliłyby poszerzyć pole badawcze i pełniej opisać to, co wydarzyło się tutaj, w polskim krajobrazie, to, $\mathrm{w}$ czym na różnych poziomach zaangażowania uczestniczyło polskie społeczeństwo. $\mathrm{W}$ podejmowanych retroaktywnie próbach rewidowania badań stawka toczy się zasadniczo o dwie kwestie: po pierwsze - o znalezienie w polszczyźnie adekwatnego odpowiednika angielskiego terminu bystander jako tego, który „stoi przy” wydarzeniach (na co zwracał uwagę m.in. Jan Tomasz Gross w artykule o znamiennym tytule Sprawcy, ofiary i inni ${ }^{2}$ ), po drugie - o inne rozumienie

1 Rozwinięcie wątków zawartych w niniejszym artykule znajduje się w książce Postronni? Zagłada w relacjach chłopskich świadków, Universitas, Kraków 2018.

2 Zob. J.T. Gross Sprawcy, ofiary i inni, „Zagłada Żydów” 2014 nr 10, t. II (Materiały), s. 885-888.
Karolina Koprowska

- magister filologii polskiej specjalności antropologiczno-kulturowej oraz judaistyki w ramach Międzywydziałowych Indywidualnych Studiów Humanistycznych UJ. Stypendystka Ministerstwa Nauki i Szkolnictwa Wyższego. Współautorka książki Szczekociny w opowieściach mieszkańców. Czasy przedwojenne i wojna i redaktorka monografii Wieś: miejsce, doświadczenie, opowieść. Kontakt: kar.koprowska@ gmail.com 
kategorii świadka w odniesieniu do postawy Polaków wobec Zagłady (co jest główną motywacją tekstów m.in. Elżbiety Janickiej czy Romy Sendyki ${ }^{4}$ ).

Sekundując obu rozpoznaniom, w analizie polskiego doświadczenia uczestniczenia w Zagładzie posługuję się terminem „postronny”. Postronność opiera się na zasadniczym paradoksie - oznacza z jednej strony bycie obecnym przy tym, co zaszło, znalezienie się „po stronie” wydarzeń czy osób (sprawcy bądź ofiary) ${ }^{5}$ - w tym sensie postronny nie mógłby pozostać bezstronny - a z drugiej odsyła do bycia na uboczu zdarzeń, do oddalenia i zdystansowania. Dawna polszczyzna potwierdza inherentną rozbieżność słowa „postronny”, odsyłającego do szeregu rozbieżnych określeń, takich jak: „poboczny, ościenny, pograniczny, sąsiedni, sąsiedzki, okoliczny, zamiejscowy, obcy, cudzoziemski". Dialektyka bliskości i oddalenia pozwala przede wszystkim uchwycić szczególne znaczenie stawania się postronnym Zagłady na wsi - specyficzne napięcie między zbliżeniem losów polskiego (chłopskiego) i żydowskiego (pod względem przestrzennym) a próbą zachowania dystansu (na poziomie doświadczenia). Tułaczka uciekających z miast i miasteczek Żydów, szukanie pomocy u mieszkańców, tworzenie kryjówek, a także akcje „polowań na Żydów” - wszystko to sprawiało, że Zagłada działa się w okolicy i konkretnym krajobrazie, zyskując tym samym wymiar lokalny. Mieszkańcy wsi byli nieustannie konfrontowani ze śmiercią Żydów; jak podkreślał Feliks Tych, „inna jest percepcja Zagłady przez świadków w dużych miastach, a inna w małych i we wsiach, gdzie Zagłada lub jej fragmenty dokonywały się z reguły na oczach miejscowej ludności polskiej i nie sposób było jej nie zauważyć"6.

3 Por. E. Janicka Pamięć przyswojona. Koncepcja polskiego doświadczenia zagładyŻydów jako traumy zbiorowej w świetle rewizji kategorii świadka, "Studia Litteraria et Historica” 2014/2015 nr 3/4, s. $148-226$.

4 Por. R. Sendyka Bystanders as Visual Subjects: Onlookers, Spectators, Observers, Gawkers, w: Probing the Limits of Categorization: The Bystander in Holocaust History, ed. by Ch. Morina, Kr. Thijs, Berghahn Books (publikacja w przygotowaniu).

5 Użycie terminu „postronny” jako ekwiwalentu bystander proponuje również zespół badawczy realizujący projekt "Nieupamiętnione miejsca ludobójstwa i ich wpływ na pamięć zbiorową, tożsamość kulturową, postawy etyczne i relacje międzykulturowe we współczesnej Polsce". Zob. Nie-miejsca pamięci. Elementarz, red. K. Jarzyńska, M. Kobielska, J. Muchowski, R. Sendyka, A. Szczepan, Ośrodek Badań nad Kulturami Pamięci UJ, Kraków 2017, s. 35.

6 F. Tych Długi cień Zagłady. Szkice historyczne, Żydowski Instytut Historyczny, Warszawa 1999, s. 24. J.T. Gross „Ten jest z Ojczyzny mojej...", ale go nie lubię, w: tegoż Upiorna dekada. Eseje o stereotypach na temat Żydów, Polaków, Niemców, komunistów i kolaboracji 1939-1948, wydanie nowe, poprawione i rozszerzone, Austeria, Kraków 2007, s. 44. 
Na piętrzenie wzajemnych zależności i natężenie emocji wpływało dodatkowo przedłużanie się sytuacji konfliktowej, w ramach której przedwojenne struktury kulturowo-symboliczne ulegały rozchwianiu, a ustalone normy moralnemu zawieszeniu.

Doświadczenie postronnego Zagłady na wsi determinowałoby - jak twierdzę - działanie w okolicy rozumianej jako przestrzeń życia, działania i doświadczenia, tworzonej w praktyce, poprzez pracę będącą codzienną aktywnością praktyczną i symboliczną, „która nadaje jej wewnętrzny rytm i wyraźnie określone trajektorie. Tę przestrzeń tworzą jej mieszkańcy zarówno w sensie kulturowym, społecznym, jak i topograficznym. Tu ważniejsza od widoku jest materialność środowiska i jego cechy determinujące sposób i rodzaj podejmowanych działań"7. Konstytutywne znaczenie aktywności ludzkiej w tworzeniu okolicy podkreśla zaproponowana przez Tima Ingolda koncepcja „krajobrazu zadanego” (taskscape), stanowiącego „zespół powiązanych działań" czy zadań podejmowanych w ramach codziennych praktyk przez daną społeczność. „Każde zadanie - jak wyjaśnia badacz - czerpie swój sens z miejsca, jakie ono zajmuje w zespole zadań, wykonywanych szeregowo lub równolegle, i zwykle przez wiele osób współpracujących z sobą"8. Okolica nie ogranicza się zatem tylko do jej fizycznego i przyrodniczego ukształtowania, ale obejmuje również wiele kontekstów: społeczny, kulturowy, afektywny czy zmysłowy. Działanie w niej - co istotne dla analizy postaw chłopskiego postronnego wobec Zagłady - wskazywałoby na konkretną formę sprawczości podmiotu, formowaną przez zależności i uwarunkowania związane z daną okolicą zamieszkania.

W badaniu doświadczenia postronnego na wsi można wyróżnić trzy rodzaje źródeł: 1) materiały z procesów sierpniowych (znakomicie wykorzystali je w swoich badaniach Jan Grabowski ${ }^{9}$ i Barbara Engelking ${ }^{10}$ ), 2) relacje pisane i mówione, wchodzące w skład literatury dokumentu osobistego oraz 3)

7 B. Frydryczak Krajobraz. Od estetyki the picturesque do doświadczenia topograficznego, Wydawnictwo Poznańskiego Towarzystwa Przyjaciół Nauk, Poznań 2013, s. 208.

8 T. Ingold Czasowość krajobrazu, przeł. B. Frydryczak, w: Krajobrazy: antologia tekstów, red. B. Frydryczak, D. Angutek, Wydawnictwo Poznańskiego Towarzystwa Przyjaciół Nauk, Poznań 2014, S. 147-148.

9 J. Grabowski Judenjagd. Polowanie na Żydów 1942-1945. Studium dziejów pewnego powiatu, Stowarzyszenie Centrum Badań nad Zagładą Żydów, Warszawa 2011.

10 B. Engelking lest taki piękny słoneczny dzień... Losy Żydów szukających ratunku na wsi polskiej 1942-1945, Stowarzyszenie Centrum Badań nad Zagładą Żydów, Warszawa 2011. 
szeroko rozumiane teksty kultury. W proponowanej tu refleksji posłużę się relacjami nadesłanymi na konkurs Opisymojej wsi, zorganizowany w pierwszej połowie 1948 roku przez Instytut Prasy „Czytelnik”. Materiały konkursowe zostały opracowane w czterotomowym wydawnictwie Wieś polska 1939-1948, pod redakcją Krystyny Kersten i Tomasza Szaroty, opublikowanym w latach 1967-1977. Regulamin konkursowy zakładał tematyczną dowolność, aczkolwiek zasugerowano trzy główne problemy: a) wieś podczas wojny i niemieckiej okupacji, b) obecne położenie gospodarcze wsi,c) kulturalne i społeczne życie wsi" ${ }^{11}$. Opowiedzenie o Zagładzie zależało zatem od decyzji i konkretnej motywacji autora relacji. Przywołując poszczególne fragmenty, staram się usłyszeć głos chłopski, wydobyć skrawki trudnych opowieści, obarczonych (prze)milczeniem - pokazać tym samym, co sami mówią o swoim doświadczeniu bycia postronnym, jakich strategii używają do opowiedzenia tego, o czym pamiętają.

\section{Działanie w okolicy}

Różne formy zaangażowania postronnych mieszczą się zasadniczo między dwiema skrajnymi postawami: aktywną przemocą (denuncjowaniem i mordowaniem Żydów) a udzieleniem tymczasowej bądź trwałej pomocy. Postawy postronnego mają zatem charakter pośredni, niejednoznaczny i dynamiczny - nie można ich zaklasyfikować jako działania sprawcy czy sprawiedliwego, choć postronny może jedną z tych ról przyjąć. Mieszkańcy wsi stawali się postronnymi poprzez wykonywanie konkretnych zadań ułatwiających Niemcom zarówno zarządzanie i nadzorowanie społeczności wiejskiej, jak i przeprowadzanie procesu eksterminacji Żydów i akcji wysiedleńczych. Znalezienie się w roli pomocnika wynikało z inicjowanego przez Niemców sposobu organizowania społeczności wiejskiej na podstawie autorytetów, m.in. sołtysa, policjanta czy komendanta ochotniczej straży pożarnej, które

11 Zob. K. Kersten, T. Szarota Wieś polska 1939-1948, t. 1-4, PWN, Warszawa 1967-1977. Jak piszą redaktorzy we wstępie do pierwszego tomu, konkurs przypadł w zasadzie na ostatni moment, w jakim można było zarejestrować obraz wsi po wojnie i rewolucyjnych zmianach roku 1944, a przed rozwojem uprzemysłowienia kraju. Ówczesna atmosfera sprzyjała rzetelnym opisom sporządzanym z poczucia odpowiedzialności za własną wieś (Wstęp, s. 9). W przygotowaniu tekstu korzystałam zarówno z tego opracowania, jak i - o ile było to możliwe - z materiałów oryginalnych zgromadzonych w Instytucie Historii PAN. Przy cytatach pochodzących z publikacji podaję numer tomu, sygnaturę i stronę; przy fragmentach oryginalnych relacji - tylko sygnaturę i - jeśli dotyczy - numer strony. 
różniły się stopniem odpowiedzialności za wspólnotę. Mieszkańcy wsi byli wyznaczani (zwykle przez sołtysa wypełniającego niemiecki rozkaz) do konkretnych zadań, np. mieli zapewniać podwody do wywożenia Żydów, należeli do straży nocnej czy warty wiejskiej, które rozpoczęły działalność po wywózkach a miały chronić wieś „przed bandytami i włóczęgami”, co w rzeczywistości oznaczało wyłapywanie Żydów ukrywających się na terenach wiejskich; mogli także zostać wybrani na zakładników gromadzkich, poręczających swoim życiem za powodzenie „polowania na Żydów”, bądź gońców wiejskich, którzy (gdy we wsi nie było telefonu) dostarczali informacje na posterunek policji ${ }^{12}$. Działaniem angażującym chłopów w Zagładę było również chowanie żydowskich ofiar, zwykle na miejscu dokonanego mordu, co przyjmowało specyficzną formę tworzenia okolicy poprzez wypełnianie jej „miejscami, które straszą”"

Jeśli weźmie się pod uwagę nastawienia postronnych do narzucanych im zadań, rola pomocnika okazuje się bardziej złożona i wymaga dodatkowych uściśleń. Przede wszystkim nie jest neutralna. Z jednej strony aktywne uczestnictwo w Zagładzie chłopscy postronni postrzegali jako sprzeczne z własnymi przekonaniami, odczuwali jako przymus, który stawia ich w moralnie ambiwalentnym świetle, czyni ich współodpowiedzialnymi za eksterminację Żydów. Z drugiej natomiast narzucona rola pomocnika dawała asumpt do przejęcia inicjatywy i przyzwolenie na samodzielne realizowanie fantazmatu. W następującym fragmencie relacji autorka pochodząca ze wsi Stoczek tak opisuje różne motywacje i sposoby działania postronnych:

Rok 1942 przyniósł masowe niszczenie Żydów. Pewnego wrześniowego ranka, jeszcze było szaro, obstawili żandarmi i żołnierze niemieccy osadę, w której byli spędzeni Żydzi z kilku gmin i zaczęła się masowa łapanka. Do pomocy użyto Ochotniczej Straży Pożarnej, która dzielnie dopomagała Niemcom. Bito, znęcano się, oblewano wodą, kopano znękaną ludność żydowską. Większość wywieziono jeszcze tego dnia do Treblinki, a resztki które uciekły, wyłapywano powoli i rozstrzelano na miejscowym cmentarzu żydowskim. Nie tylko Niemcy, ale i Polacy rzucili się do grabieży mienia żydowskiego. Niektórzy Polacy złapawszy

12 Zob. J. Grabowski Judenjagd..., s. 71-86.

13 Zob. R. Sendyka Miejsca, które straszq̨ (afekty i nie-miejsca pamięci), "Teksty Drugie" 2014 nr 1, s. 84-102. 
gdzieś kryjącego się Żyda, obdzierali go nie tylko ze złota i ubrania, ale nawet młode panny żydowskie ze czci i wtedy dopiero oddawali w ręce Niemców. Inni za wysokie sumy obiecywali ich przechować, a zabrawszy im wszystko oddawali Niemcom. Byli także i tacy którzy nie chcieli nic żydowskiego, ale nie chcieli ich także przechowywać, za co Żydzi nie mieli żalu. Kilka jednak rodzin żydowskich przeżywszy straszną gehennę żyją do dziś i wiele mogliby o tym powiedzieć. [sygn. 847, s.4, pisownia oryg.]

Akcję wyłapywania i wywożenia Żydów autorka pokazuje w swojej relacji jako wspólne działanie Niemców i Polaków, którego specyfikę ujawnia jedno zdanie tej opowieści: „Do pomocy użyto Ochotniczej Straży Pożarnej, która dzielnie dopomagała Niemcom"14. Uczestniczenie chłopskich pomocników (a szczególnie straży pożarnej) opiera się na zasadniczym paradoksie przymusu i dobrowolności - działają oni z polecenia Niemców (zostali „użyci do pomocy"), co jednocześnie nie wyklucza ich spontanicznej i niewymuszonej aktywności („dzielnego dopomagania”) ${ }^{15}$. Ukazując konkretne czynności uczestników zdarzenia, autorka używa dwóch form czasowników: bezosobowej, gdy mowa o aktach bicia, dręczenia i mordowania Żydów (np. „Bito, znęcano się, oblewano wodą, kopano znękaną ludność żydowską",,większość wywieziono", „wyłapywano powoli i rozstrzelano na miejscowym cmentarzu żydowskim") i osobowej, kiedy opisywane jest rabowanie żydowskiego mienia i wydawanie Żydów. Wydaje się, że w ten sposób różnicowane i niuansowane jest zaangażowanie postronnych: straży pożarnej biorącej udział w bezpośrednich aktach przemocy naruszających granicę życia, rabujących chłopów przekraczających granicę godności, a także tych, którzy chcieli pozostać na pozycji neutralnej (odmawiali pomocy i nie rabowali). Za obdzieraniem ze złota i ubrania, gwałceniem Żydówek, wydawaniem Niemcom

14 Warto wspomnieć, że fragment cytowanej relacji w opracowaniu Krystyny Kersten i Tomasza Szaroty jest skrócony właśnie w połowie tego zdania (ze względu na rok wydania publikacji można domyślać się wpływu cenzury lub autocenzury). Informacja o dobrowolnej aktywności postronnych na wsi zostaje $w$ ten sposób anulowana, a opowieść utrzymana w trybie usprawiedliwiającym i ograniczającym udział chłopów w Zagładzie.

15 Ze świadectw i materiałów z procesów sierpniowych znane są zdarzenia wskazujące na samodzielne działanie lokalnych oddziałów ochotniczej straży pożarnej w wyłapywaniu Żydów. O wstrząsającym akcie torturowania i zamordowania miejscowych Żydów w Gniewczynie, zainicjowanym przez strażaków, opowiadają Tadeusz Markiel (naoczny świadek) i Alina Skibińska. Zob. tychże "Jakie to ma znaczenie, czy zrobili to z chciwości?"Zagłada domu Trynczerów, Stowarzyszenie Centrum Badań nad Zagładą Żydów, Warszawa 2011. 
stoi bowiem przyzwolenie na cierpienie wyłapywanych i przekonanie o ich nieuchronnej śmierci, którą ostatecznie zada im inny podmiot ukryty za formami bezosobowymi. Odpowiedzialność za pozbawianie życia Żydów rozmywa się w takiej narracji, sprawstwo pozostaje niewypowiedziane i pozbawione konkretnego imienia.

\section{Doznania zmysłowe jako oznaki Zagłady}

Stawanie się postronnym determinowałaby przede wszystkim sama obecność przy danym zdarzeniu, której nieuchronna konieczność wynika nie tyle z wyboru postronnego, ile jego miejsca urodzenia lub przebywania - ze znalezienia się w danej sytuacji. Wiedza o ukrywających się w okolicy Żydach i eksterminacyjnych działaniach była zatem powszechna, jakkolwiek pochodziła z różnych źródeł. Mogła być zasłyszana (z plotek jako najszybszej formy przekazywania informacji we wspólnocie), rozpoznana na podstawie śladów, oznak, dźwięków pozostawionych w okolicy (chłopi znający doskonale swoją okolicę mieli tę przewagę nad ukrywającymi się Żydami, że wszelkie zmiany w krajobrazie były dla nich łatwiej zauważalne) lub też suponowana, domyślana na podstawie pogłosek, podejrzeń czy przesłanek.

Podejmowaną w okolicy aktywność podmiot rozpoznaje za pomocą różnych zmysłów. Jak podkreśla Ingold, „krajobraz zadany zakłada obecność kogoś, kto poddaje obserwacji i nasłuchuje: krajobraz zadany musi być wypełniony ludźmi, którzy sami obserwują i którzy «działają zwrotnie» w trakcie swojego zamieszkiwania. [...] krajobraz zadany nie istnieje jako aktywność, tylko jako interaktywność"16. W kontekście wiejskim wzrok nie jest jedynym narzędziem identyfikowania i doświadczania Zagłady, lecz współistnieje z innymi, tworzącymi okolicę doznaniami zmysłowymi, które są percypowane jako oznaki eksterminacji. Doświadczenie postronnego, aktywowane na poziomie somatyczno-zmysłowym, ma więc w pewnym stopniu samoistny charakter, zachodzi niezależnie od świadomej decyzji podmiotu. W relacji mającej formę epistolarną autorka ze wsi Brzeszcze odnotowuje:

A gdy o kilometr od ciebie świecą ci do ślepi reflektory jawiszowickiego lagru, o $5 \mathrm{~km}$ oświęcimskiego, gdy od rana do wieczora wyją w pobliżu kilkusetne sfory esesmańskich psów, widzisz każdy wieczór łunę w Brzezince i gdy na koniec wiosną czy latem nie czujesz nic prócz smrodu

16 T. Ingold Czasowość krajobrazu..., s. 154. 
spalonych ciał, cóż byś ty zrobił? [...] Naszym świętym obowiązkiem było patrzeć na Rajsko, Brzezinkę. [sygn. 1461, pisownia oryg.]

W odniesieniu do percepcji zmysłowej środowiska Urry i Macnaghten stwierdzali, że wszystkie zmysły są przestrzenne (geograficzne) - okolica jest zatem po części konstruowana przez te różne doznania zmysłowe ${ }^{17}$. Wymienione w liście przejawy zmysłowej percepcji: wycie esesmańskich psów, widok łuny w Brzezince oraz smród palonych ciał, intensyfikują trudną do zniesienia bliskość cudzej śmierci. Dźwięki i zapachy narzucają się, dochodzą do postronnego z zewnątrz, naruszając jego pozycję bezpiecznego oddalenia. W kolejnej relacji czytamy o rozstrzelaniu Żydów w Przyszowej, dekodowanym na podstawie usłyszanego warkotu motorów i strzałów:

W tym czasie hydra germańska zaczęła wyniszczać wszystko co polskie. Równoważnikiem wzmagającego prześladowania polskości były tajne organizacje, które w tym czasie zaczęły powstawać. Coraz częściej ciszę nocną mącił warkot motorów, a następnie rozlegały się strzały. To Gestapo z Nowego Sącza rozstrzeliwało Żydów, aby skończyć już z nimi i zacząć z Polakami. W naszej wsi rozstrzeliwano około 60 Żydów i tyleż katolików. [WP, t. II, nr 234 (1232), s. 309]

Autorka - i jak można się domyślać, inni okoliczni mieszkańcy - dekodowała warkot motorów i strzały jako dokonującą się właśnie eksterminację Żydów (oczywiście nie można wykluczyć wiedzy uzyskiwanej ex post z zasłyszanych opowieści, plotek czy pogłosek). Przeraźliwe dźwięki, identyfikowane jako zapowiedź i zarazem realizacja śmierci, zmniejszały dystans postronnych wobec cudzego cierpienia (bliskość nie byłaby zatem warunkiem tylko spojrzenia). Podobnie jak słuch, ,powonienie zapewnia bardziej bezpośrednie i mniej zaplanowane spotkanie ze środowiskiem, i to takie, którego nie można włączyć i wyłączyć"18. Yi-Fu Tuan akcentował również momentalność i bezpośredniość woni i jako taką przeciwstawiał abstrakcyjnej i kompozycyjnej charakterystyce widzenia' ${ }^{19}$. W przywołanym wcześniej liście autorka podkreślała: „Naszym świętym obowiązkiem było patrzeć na Rajsko, Brzezinkę”.

17 Zob. J. Urry, P. Macnaghten Zmysłowe postrzeganie przyrody, w: tychże Alternatywne przyrody. Nowe myślenie o przyrodzie i społeczeństwie, przeł. B. Baran, Scholar, Warszawa 2005, s. 148. Tamże, s. 172.

19 Zob. Yi-Fu Tuan Przestrzeń i miejsce, przeł. A. Morawińska, PIW, Warszawa 1987. 
Patrzenie traktowane jako etyczny imperatyw postronnego jest faktycznie zależne od postronnego, może on zarządzać własnym spojrzeniem (patrzeć lub spuścić wzrok). W tym kontekście spojrzenie daje dostęp do wiedzy o Zagładzie i zarazem pozwala zachować wobec niej dystans. Warto jednak zwrócić uwagę, że wzrok ujawnia tu swój ambiwalentny charakter. Autorka używa bowiem dwóch określeń aktywujących różne znaczenia spojrzenia z jednej strony odwołuje się do patrzenia, czyli skierowania wzroku na dany obiekt i co więcej, zajmowania postawy naocznego świadka, a z drugiej mówi o „świeceniu do ślepi”, które pozbawia podmiot wzroku i jego sprawczości.

\section{Zaangażowanie afektywne}

Częścią doświadczenia postronnego, które konstytuuje topograficzna i zmysłowa bliskość, jest również to, co afektywne, somatyczne, przedwyrażalne i przedsymboliczne. Formy zaangażowania postronnych w Zagładę obejmowałyby więc nie tylko konkretne działania podejmowane w okolicy, ale również pobudzenia i intensywności afektywne pojawiające się w reakcji na cudze cierpienie - naruszające tym samym budowany świadomie dystans. Autor, pochodzący z Okrzei, tak opowiada o eksterminacji miejscowych Żydów:

No i nareszcie przyszedł straszny dzień, zaczęło się troszkę rozbryzgiwać na wschodzie. A już Niemcy i Ukraińcy obtoczyli Okrzeję z bronią maszynową. Spędzili wszystkich na rynku, bo tak jest środek naszej wsi nazywany z dużym placem. Odłączyli Żydów okrzejskich, a obcych porozbierali do bielizny, kazali im śpiewać „Alleluja” i tańczyć, pozabierali im pieniądze, biżuterię, a ubrania na razie na kupę. Potem kazali im się kłaść na ziemię twarzą do ziemi; jak się kładli na ziemię, to zrobił się j e d e n wspólny jęk, jęk straszny, jakby grobowy, spod ziemi, aż w sobie cośściskało, aż ciarki człowieka stojącego na boku przechodziły. [WP,t.III, nr 106(1437) s.172; wyróż. - K.K.]

"Człowiek stojący na boku” określa tu jedynie miejsce postronnego w układzie przestrzennym, pod względem cielesnym i afektywnym sytuuje się on bowiem w obrębie wydarzenia, cierpienie Żydów dotyka go wewnętrznie (odczuwa wewnętrzny ścisk i ciarki na ciele). Jęk skazanych na śmierć Żydów, straszliwy i niemal apokaliptyczny, zdaje się w tej opowieści materializować, staje się jęlkiem samym - „jednym i wspólnym” - który oddziela się niejako od tych, z których się wydobywa. Próbując uchwycić natężenie 
i grozę tego jęku, autor sytuuje jego źródło w ziemi, w grobie - ten dojmujący dźwięk pochodzi zatem już z zaświatów, od ludzi już umarłych.

Efekty afektu, uwalnianego w momencie współ-czucia, wpływają również na formę przekazywanej opowieści i jako takie pozwalają identyfikować stojące za nią doświadczenie. Takie relacje ujawniają charakterystyczne rozedrganie, które budują kompulsywne powtórzenia tych samych fraz czy nagłe zerwania toku opowieści. Jako przykład takiego zapisu afektywnego doświadczenia posłuży następujący fragment, dotyczący akcji likwidacyjnej w getcie w Dąbrowie Tarnowskiej, aczkolwiek opowiadanej z perspektywy kobiety mieszkającej na wsi²0:

Serce pękało patrząc na wszystko. Tam czapka leży na ulicy, tam laska, tam się wyrzuca z drugiego piętra chorego staruszka na podwórko, tam się dobija kulą z rewolweru, tam z drugiego piętra się dziecko małe rzuca na kamienie podwórka; dziecko się rozbija, matka rzuca się za dzieckiem. Tam się z wózkiem spycha dziecko z ganku pierwszego piętra, tam bierze się znów dziecko z wózeczka matki - za nóżki, uderza się o róg domu, móżdżek wypływa, matka rzuca się na żołdaka, on kulą z rewolweru kończy jej życie. Tam kopie się dziurę, mało postrzelaną osobę wrzuca się weń i synka nieletniego, zdrowego rzucają ku niej, posypuje wapnem i zasypuje się ziemią. Tam wożą pełne wozy - takie, na których się w lecie nawóz wozi - pełne ludzi, napchany, jęki tylko słychać i krew z wozu leje się po ulicach; za wozami jak z beczki. Wszystkie dzielnice żydowskie i podwórka płyną we krwi. Już domy puste, gdzieniegdzie jeszcze sama administracja, a zatrudnionych jest około 10 ludzi. Zmienili się tylko ludzie. [WP, t. II, nr 273(910), s. 365]

Fragment relacji stanowi rodzaj dynamicznej enumeracji zobaczonych scen cierpienia i śmierci Żydów. Wprowadzanie kolejnych obrazów za pomocą anafory „tam” sprawia wrażenie kompulsywnego gromadzenia przeżyć postronnego uczestnika oraz intensyfikowanie afektywnych pobudzeń. Autorka wyrzuca z siebie poszczególne doznania i wspomnienia, niosące traumatyczny ciężar, próbuje tym samym wypowiedzieć nadmiar swojego doświadczenia. Czasowy dysonans, pod wpływem którego opowieść się rozpada, sytuuje opowieść/wspomnienie na granicy teraźniejszości i przeszłości.

20 Autorka relacji pochodzi z Wieprzca, w czasie wojny pracowała u rodziny żydowskiej w Dąbrowie Tarnowskiej. Była naocznym świadkiem akcji likwidacyjnej. 
Rozpoczynający powyższy akapit dopisek: „Serce pękało patrząc na wszystko", ma charakter dokonywanej post factum konceptualizacji własnego doświadczenia, wyrażenia za pomocą obrazowej metafory odczuwanej wówczas rozpaczy. Następująca dalej opowieść, której rytm wyznacza anafora „tam”, oddaje postrzeżeniowy tryb doświadczania Zagłady, poprzez rejestrowanie szczątkowych obrazów nieukładających się w zrozumiałą całość. Interesujące w tym fragmencie jest również użycie form bezosobowych, budujących obraz samoistnie dziejących się wydarzeń. Strategia ta podkreśla przede wszystkim odczuwaną przez postronną obserwatorkę bezradność, wyraża w ten sposób jej poczucie, że nie mogła nic zrobić (nie wiedziała, co mogłaby wówczas zrobić). Ten rodzaj zawieszenia działania i afektywnego chaosu okazuje się niezwykle dojmujący.

\section{Chłopski postronny jako okoliczny - w ramach podsumowania}

Doświadczenie postronnego na wsi determinuje działanie w okolicy obejmujące trzy aspekty: kulturowy (chłopską kulturę i jej imaginarium symboliczne), społeczny (dotyczący relacji międzyludzkich: polsko-polskich, polsko-żydowskich, żydowsko-żydowskich) oraz topograficzny (odwołujący się do ukształtowania wiejskiej przyrody). Nawiązując do zarysowanego wcześniej pojęcia „okolicy” i jej szczególnego znaczenia w kontekście Zagłady, postawę chłopskiego postronnego można dookreślić terminem „okoliczny”, nazywając tego, który funkcjonuje i działa poprzez interakcje z otaczającym go środowiskiem, oraz aktywnościami wpływającymi na ukształtowanie okolicy. Intuicję tę potwierdza Słownik warszawski, zgodnie z którym istniało kilka pokrewnych postronnemu określeń, takich jak: sąsiedni, sąsiedzki i okoliczny właśnie. Warto również wspomnieć, że termin „okolicznik” oznaczał w dawnym użyciu „kogoś z okolicy” lub „sąsiada okolicznego". Nie uchylając jednak całkowicie pierwszego znaczenia „okolicznika”, związanego z terminologią językoznawczą, można stwierdzić, że status okolicznego wyznacza relacja zależności od podmiotu nadrzędnego. Swoje bycie dostosowuje on do zasad i reguł wynikających z funkcjonowania w konkretnej konfiguracji społecznej, która w warunkach okupacyjnych przybrała postać wzajemnego zakładnictwa - polsko-żydowskiego i polsko-polskiego. Uchwycenie złożoności doświadczenia postronnych na wsi oraz stopnia ich zaangażowania w Zagładę wydaje się więc możliwe dzięki analizie kontekstowej koncentrującej się na sytuacji, w jakiej żyli i działali postronni, oraz uwarunkowaniach przyjmowanych przez nich ról zależnych 
od rozporządzeń okupanta, niepisanych reguł rządzących wiejską wspólnotą, a także własnego wyboru i decyzji ${ }^{21}$.

Stawanie się postronnym-okolicznym - ze względu na różnorakie formy, jakie decydowały o jego zaangażowaniu - można rozpatrywać na kilku poziomach: 1) aktywnego działania zakładającego wykonywanie bądź podejmowanie konkretnych zadań, 2) percepcji zmysłowej będącej podstawą zdobywania wiedzy o dziejącej się w okolicy Zagładzie, 3) obecności mającej wymiar cielesno-afektywny i wreszcie 4) trudnej artykulacji opierającej się na (prze)milczeniu (postronny jest niemym i milczącym świadkiem - nie dysponuje odpowiednim językiem, za pomocą którego mógłby pojęciowo opanować to, co przeżywa(ł) i w czym uczestniczy(ł), pozostawiając tym samym szczątkowe narracje, albo też decyduje o tym nie mówić).

Zarówno ci, którzy pomagali Żydom w czasie wojny, jak i ci, którzy ich zabijali, byli piętnowani przez wiejską wspólnotę ${ }^{22}$. Stanowili bowiem źródło wstydu zagrażającego zbiorowej tożsamości mieszkańców, z którą się identyfikowano ${ }^{23}$.Ten społeczny ostracyzm wskazuje paradoksalnie na to, że normą zachowań polskiego społeczeństwa w czasie Zagłady była postronność z perspektywy wspólnoty osoby, które przekroczyły jej granicę, nie dostosowały się do podzielanej przez mieszkańców postawy. Tym samym mogły one potwierdzić przyzwalającą na śmierć obojętność i „poboczne zaangażowanie" większości². Mechanizm ten ujawnia jeszcze coś więcej - że postronne uczestnictwo jest nie-do-zniesienia, stawia tego, który znajdzie się przy cudzym cierpieniu i śmierci, w moralnie dwuznacznej pozycji. W tym sensie - nie tylko podejmowania konkretnego działania, ale afektywno-zmysłowej

21 Por. H. Edgren The Project "Bystanders - Does It Matter?", w: Looking at the Onlookers and Bystanders. Interdisciplinary Approaches to the causes and consequences of passivity, ed. by H. Edgren, The Living History Forum, Edita, Västerås 2012, s. 15.

Przywołam dwa przykłady. W filmie Pawła Łozińskiego Miejsce urodzenia jeden z rozmówców wspomina, że zabójca Abrama Grynberga przeniósł się do innej wsi, gdyż był wyśmiewany. Z kolei osoby, które pomagały Żydom w czasie wojny, bały się o tym mówić publicznie, były piętnowane przez lokalną społeczność (znamiennym przykładem jest tu historia Antoniny Wyrzykowskiej, która ukrywała ośmiu Żydów w Jedwabnem, po wojnie z powodu niechęci i wrogości swoich sąsiadów wyjechała z miasteczka, a następnie emigrowała do Stanów Zjednoczonych). Zob. J.T. Gross Sąsiedzi. Historia zagłady żydowskiego miasteczka, Fundacja Pogranicze, Sejny 2000.

Zob. Wobec obcych. Zagrożenia psychologiczne a stosunki międzygrupowe, red. M. Kofta, M. Bilewicz, PWN, Warszawa 2011, s. 27. 
obecności - postronny nie może uchylić się od swojego zaangażowania, pozostać na zewnątrz dziejących się w jego okolicy wydarzeń. Dori Laub, wyróżniając świadków wewnętrznych i zewnętrznych (wśród których wymieniał m.in. najbliższego sąsiada, przyjaciela, instytucje społeczne, np. policję, oraz potencjalnych ratujących), przekonywał jednocześnie, że

Było ponadto nie do pojęcia, aby jakikolwiek uczestnik wydarzeń (historical insider) mógł się wystarczająco oderwać od trującej siły wydarzenia, by zachować pełną jasność oraz dystans świadka, czyli wystarczająco się odseparować od wnętrza, aby pozostać całkowicie na ze w nątrz zamkniętych (trapping) ról i wynikających z nich tożsamości zarówno ofiary, jak i kata. Żaden obserwator nie mógł pozostać niesplamiony, to znaczy zachować spójność - całość i oddzielenie - która pozostałaby czysta (uncompromised), nienaruszona poprzez sam fakt bycia świadkiem ${ }^{25}$.

Postronność, będąca formą „pobocznego” działania i uczestniczenia, bycia obecnym przy danym zdarzeniu, ma charakter sytuacyjny i kontekstowy, warunkuje ją bowiem konkretna sytuacja, w pobliżu której znajdzie się postronny, czy okolica, którą zamieszkuje $\mathrm{e}^{\mathbf{2 6}}$. Świadczenie odnosiłoby się natomiast do poziomu doświadczenia i artykulacji - świadkiem jest zatem ten, kto nie tylko coś przeżył i posiada na ten temat pewną wiedzę, ale również może w jakiś sposób (werbalnie bądź pozawerbalnie) wyrazić swoje doświadczenie i przekazać je dalej ${ }^{27}$. Polski postronny zdaje się zatem kwestionować własny potencjał świadczenia, odmawia zostania świadkiem, gdyż gest ten ujawniłby jego uwikłanie w doświadczenie Zagłady.

25 D. Laub Zdarzenie bez świadka: prawda, świadectwo oraz ocalenie, przeł. T. Łysak, „Teksty Drugie” $2007 \mathrm{nr}$ 5, s. 122.

Podobny sposób definiowania postronnego (bystandera) proponuje Mary Fulbrook, zob. tejże A Small Town Near Auschwitz: Ordinary Nazis and the Holocaust, Oxford University Press, Oxford 2013, S. 15.

27 Zob. G. Agamben Co zostaje z Auschwitz, przeł. S. Królak, Sic!, Warszawa 2008, s. 15. 


\section{Abstract}

\section{Karolina Koprowska}

JAGIELLONIAN UNIVERSITY (CRACOW)

Surroundings: Dimensions of Being a Bystander in Rural Poland

Koprowska brings studies on cultural landscapes - including terms such as "surroundings" and the "taskscape" - to bear on passages from peasants' narratives submitted to a competition held in 1948 and titled "Descriptions of My Countryside". She categorizes peasant onlookers during the Holocaust and identifies four levels of their involvement: deliberate actions aimed at creating the surroundings (fulfilling specific tasks), sensual perception, presence that has a bodily and affective dimension, as well as silence and the difficulty of articulation.

\section{Keywords}

bystander, witness, Holocaust, village, landscape 